\title{
Pengaruh Current Ratio, Debt to Equity Ratio, Net Profit Margin, dan Ukuran Perusahaan Terhadap Harga Saham Pada Perusahaan Otomotif Dan Komponen Yang Terdaftar Di BEI Tahun 2013-2017
}

\author{
Adolf Jelly Glen Lombogia \\ Universitas Prima Indonesia \\ adolflombogia@gmail.com \\ Chirike Vista \\ Universitas Prima Indonesia \\ chirikevista17@gmail.com

\section{Siti Dini} \\ Universitas Prima Indonesia \\ siti.dni@gmail.com
}

\begin{abstract}
Abstrak
Harga saham yang terdapat pada masing-masing perusahaan yang terdaftar di BEI sangat berpengaruh dalam menjalankan kinerja perusahaan. Oleh karena itu, peneliti melakukan penelitian dengan menggunakan variabel terikat yaitu harga saham dan diikuti oleh variabel bebasnya yaitu current ratio, debt to equity ratio, net profit margin, dan ukuran perusahaan. Penelitian ini dilakukan dengan menggunakan metode kuantitatif dan jenis data adalah data sekunder. Populasi penelitian sebanyak 13 perusahaan dan teknik pengambilan sampel menggunakan purposive sampling sebanyak 6 perusahaan dalam waktu 5 tahun dengan total 30 sampel. Model analisis yang digunakan yaitu analisis regresi linear berganda. Penelitian yang dihasilkan adalah secara bersamaan current ratio, debt to equity ratio, net profit margin, dan ukuran perusahaan berpengaruh signifikan terhadap harga saham. Hipotesis yang diuji adalah ukuran perusahaan berpengaruh positif dan signifikan terhadap harga saham, namun current ratio, debt to equity ratio, dan net profit margin tidak berpengaruh signifikan terhadap harga saham.

Kata Kunci Current Ratio, Debt To Equity Ratio, Net Profit Margin, Ukuran Perusahaan dan Harga Saham.
\end{abstract}

\section{I.PENDAHULUAN}

\subsection{Latar Belakang}

Di era globalisasi saat ini banyaknya kuantitas perusahaan otomotif merupakan salah satu bukti, bahwa industri otomotif di Indonesia menarik perhatian banyak pihak. Suatu perusahaan diharapkan dapat terus berkembang. Sementara pengembangan tersebut membutuhkan modal. Modal itu sendiri menjadi salah satu aspek penting dalam perusahaan baik dalam pembukuan bisnis maupun pengembangannya. Oleh karena itu, perusahaan harus menentukan seberapa banyak modal yang diperlukan untuk membiayai perusahaan. Sumber dana bagi perusahaan dapat diperoleh dari dalam maupun luar perusahaan. Dana dari dalam perusahaan, yaitu melalui laba 
ditahan dan depresiasi serta dana dari luar perusahaan yaitu dana yang berasal dari para kreditur dan investasi asing. Namun dana yang berasal dari pinjaman kreditur, serta investasi asing dirasa masih kurang. Oleh sebab itu banyak perusahaan yang memilih pasar modal sebagai sarana penambah modal mereka.

Indeks Harga Saham Gabungan (IHSG) sempat mengalami penurunan yang drastis sehingga kondisi seperti ini cukup mengkhawatirkan para pelaku pasar. Pada era saat ini, perekonomian Indonesia tergolong sulit khususnya di subsektor otomotif dan komponen. Sektor ini dituntut untuk menciptakan kreasi baru pada produknya agar dapat bersaing secara global. Namun, adanya krisis pada era saat ini menyulitkan para emiten untuk berkembang, hal ini disebabkan oleh kategori kebutuhan masyarakat Indonesia pada sektor ini termasuk kategori kebutuhan sekunder bahkan tersier.

Harga saham dapat dilihat berdasarkan aktiva yang dihasilkan apakah bersifat likuid atau tidak melalui current ratio, kewajiban yang diterpenuhi oleh ekuitasnya melalui debt to equity ratio, laba yang dihasilkan melalui penjualan bersihnya melalui net profit margin, dan pertumbuhan aset yang dilhat melalui ukuran perusahaan tersebut secara periodik. Oleh karena itu penelitian ini menggunakan variabel bebas yang mempengaruhi harga saham yaitu current ratio, debt to equity ratio, net profit margin, dan ukuran perusahaan.

Setiyawan \& Pardiman (2014) dalam penelitiannya "Pengaruh Current Ratio, Inventory Turnover, Time Interest Earned dan Return on Equity Terhadap Harga Saham Pada Perusahaan Manufaktur Sektor Barang Konsumsi Yang Terdaftar di BEI Periode 2009-2012" menyatakan variabel Current Ratio secara parsial dan simultan berpengaruh positif dan signifikan terhadap harga saham. Penelitian lain dilakukan oleh Faleria (2017) dalam penelitiannya "Pengaruh Current Ratio, Net Profit Margin dan Earning Per Share Terhadap Harga Saham di Bursa Efek Indonesia (Studi Kasus Pada Sub Sektor Food And Beverages)" menyatakan variabel current ratio dan net profit margin secara parsial tidak berpengaruh dan secara simultan tidak signifikan. Penelitian lain dilakukan oleh Valianti (2018) dalam penelitiannya "Pengaruh Debt to Assets Ratio, Debt to Equity Ratio, Return on Assets dan Net Profit Margin Terhadap Harga Saham Pada Perusahaan Indeks LQ-45 di Bursa Efek Indonesia" menyatakan variabel net profit margin secara parsial dan simultan berpengaruh positif dan signifikan terhadap harga saham.

Safitri (2016) "Pengaruh PER, ROA, dan DER terhadap Harga saham pada perusahaan sub sektor lembaga pembiayaan di Bursa Efek Indonesia" menyatakan variabel Debt to Equity Ratio secara parsial dan simultan berpengaruh positif dan signifikan terhadap harga saham.

Novitasari \& Herlambang (2015) "Pengaruh Current Ratio, Total Assets Turnover, Debt to Equity Ratio, dan Return on Equity terhadap Harga Saham pada Perusahaan Yang Terdaftar di JII Periode 2009-2013" menyatakan variabel Current Ratio dan Debt to Equity Ratio secara parsial dan simultan tidak berpengaruh terhadap harga saham.

Wehantouw, dkk (2017) "Pengaruh Struktur Modal, Ukuran Perusahaan, dan Profitabilitas Terhadap Harga Saham pada Perusahaan Industri Sektor Makanan dan Minuman yang Terdaftar di Bursa Efek Indonesia Periode 2012-2015." menyatakan variabel size secara parsial tidak berpengaruh terhadap harga saham sedangkan Zaki, dkk (2017) "Pengaruh Profitablitas, Leverage Keuangan dan Ukuran Perusahaan Terhadap Harga Saham (Studi Pada Perusahaan Manufaktur Yang Terdaftar di Bursa Efek Indonesia Periode 2005-2014)" menyatakan Ukuran perusahaan secara parsial bepengaruh dan signifikan terhadap harga saham.

\section{I.2. Teori Pengaruh}

\section{I.2.1. Pengaruh Current Ratio Terhadap Harga Saham}

(Rahmadewi \& Abundanti, 2018). current ratio yang rendah akan menyebabkan harga pasar saham ikut menurun, sebaliknya current ratio yang tinggi akan meningkatkan harga saham tetapi current ratio yang terlalu tinggi tidak menjamin keuntungan dalam perusahaan. 
Setiyawan \& Pardiman, 2014). Current ratio yang semakin membaik akan mempengaruhi peningkatan harga saham, karena perusahaan mampu untuk menutupi hutang lancarnya. Hal ini akan menarik investor untuk berinvestasi dalam bentuk saham.

(Nur'aidawati, 2018). besarnya nilai current ratio akan berpengaruh bagi investor untuk menanamkan modalnya, karena current ratio yang tinggi dapat meningkatkan kenaikan harga saham pada suatu perusahaan.

Semakin besar peningkatan current ratio maka akan meningkatkan harga saham, begitu pula permintaan akan saham semakin naik. Sebaliknya apabila current ratio semakin kecil akan menyebabkan permintaan akan saham tersebut menurun karena harga sahamnya cenderung menurun dan dapat mengurangi kepercayaan investor.

\section{I.2.2. Pengaruh Debt to Equity Ratio Terhadap Harga Saham}

Batubara (2017) Nilai Debt to equity ratio yang semakin tinggi tidak baik bagi perusahaan dikarenakan hutang tinggi akan mempengaruhi peningkatan suku bunga. Suku bunga yang tinggi akan menyebabkan menurunnya keuntungan dan harga saham, begitu pula sebaliknya apabila nilai Debt to equity ratio semakin rendah maka akan baik bagi keuntunga dan harga saham perusahaan.

Safitri (2016) Nilai Debt to equity ratio yang tinggi akan dikelola sebagai dana pihak ketiga, hal dilakukan agar meningkat laba. Peningkatan laba juga akan disertai oleh kenaikan harga saham pada perusahaan dan akan investor akan berniat untuk berinvetasi.

Dewi \& suaryana (2013) Nilai Debt to equity ratio yang tinggi akan beresiko terhadap keputusan berinvestasi oleh investor, dikarenakan akan dapat memicu penurunan harga saham dan mengurangi permintaan akan saham tersebut.

Perusahaan yang dengan lancar membayar kewajibannya akan menyebabkan nilai Debt to equity ratio-nya menurun. Hal ini sangat baik bagi investor karena harga saham akan meningkat, akan tetapi perusahaan yang memiliki tingkat hutang tinggi atau kewajiban yang besar akan menarik minat investor untuk berinvestasi karena akan berakibat pada penurunan harga saham.

\section{I.2.3. Pengaruh Net Profit Margin Terhadap Harga Saham}

Hutami (2012) Net profit margin yang semakin besar akan berpengaruh positif terhadap kinerja perusahaan, maka harga saham akan meningkat karena permintaan akan saham perusahaan tersebut akan bertambah.Hal ini dikarenakan perusahaan dapat meningkatkan laba melalui penjualannya, dan perusahaan juga dapat menutupi biaya operasionalnya.

Watung \& Ilat (2016) Nilai Net profit margin akan tinggi jika laba perusahaan tersebut meningkat, maka harga saham juga akan ikut meningkat. Hal ini akan menarik investor untuk berinvestasi karena harga pasar akan naik pada perusahaan tersebut.

Amalya (2018) Net profit margin memiliki pengaruh yang tinggi terhadap kenaikan harga saham, karena kinerja perusahaan dapat dilihat berdasarkan hasil dari nilai Net profit margin-nya. Perusahaan yang memiliki kinerja yang baik akan mendapatkan laba yang tinggi pula dan akan berdampak terhadap peningkatan harga saham.

Nilai Net profit margin yang semakin tinggi menyebabkan perusahaan tersebut memiliki potensi untuk mengalami keuntungan melalui penjualannya. Dengan keuntungan yang diperoleh dari perusahaan maka akan berpeluang harga saham perusahaan tersebut akan meningkat dan harga pasar juga akan naik menyebabkan investor berminat untuk berinvestasi berupa saham.

\section{I.2.4. Pengaruh Ukuran Perusahan Terhadap Harga Saham}

Sukarno dkk (2016) Besar kecilnya ukuran perusahaan dapat dilihat berdasarkan aset yang dimiliki. Aset yang besar akan menarik kepercayaan investor untuk berinvetasi pada 
perusahaan tersebut. Hal ini menyebabkan harga saham juga akan tinggi.

Bernardin \& Pebryyanti (2016) Semakin besar ukuran perusahaan tersebut atau asetnya maka akan semakin tinggi juga harga saham nya. Sebaliknya harga saham yang rendah akan menunjukkan bahwa ukuran perusahan tersebut atau asetnya semakin kecil.

Zaki dkk (2017) Ukuran perusahaan yang besar akan memiliki pengaruh yang baik bagi tingkat kualitas dan perfoma perusahaan. Hal ini dapat meyakinkan investor untuk menanamkan modalnya. Harga saham perusahaan juga akan ikut bergerak meningkat karena banyaknya permintaan akan saham perusahaan tersebut.

Ukuran perusahaan yang semakin besar akan menjadi tolak ukur yang baik bagi perfoma dan kualitas suatu perusahaan, karena tidak diragukan lagi bahwa aset yang besar akan memiliki harga pasar yang besar pula. Investor tidak akan mengurungkan niatnya berinvestasi karena harga saham nya juga akan meningkat.

\section{I.3. Kerangka Konseptual}

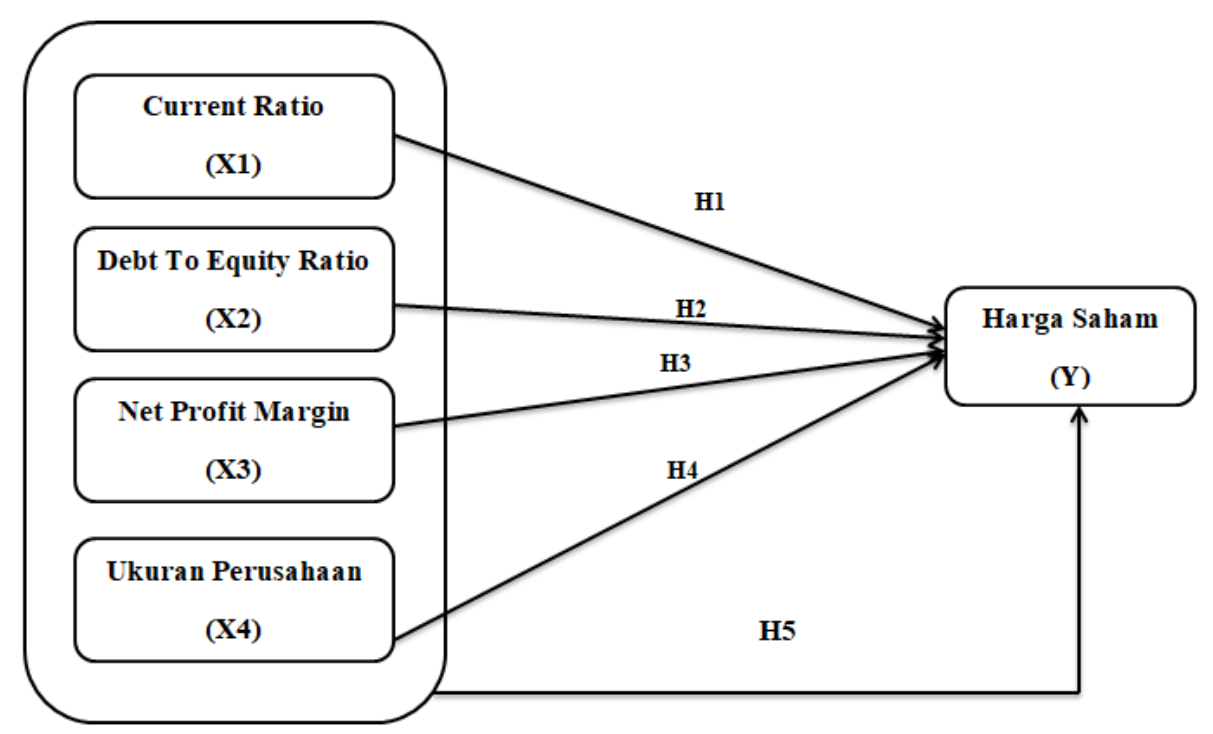

Gambar 1.1 : Kerangka Konseptual

\subsection{Hipotesis}

Adapun hipotesis dalam penelitian ini yaitu :

1. Current ratio berpengaruh secara parsial terhadap harga saham pada perusahaan sektor otomotif dan komponen tahun 2013-2017.

2. Debt to equity ratio berpengaruh secara parsial terhadap harga saham pada perusahaan sektor otomotif dan komponen tahun 2013-2017.

3. Net Profit Margin berpengaruh secara parsial terhadap harga saham pada perusahaan sektor otomotif dan komponen tahun 2013-2017.

4. Ukuran perusahaan berpengaruh secara parsial terhadap harga saham pada perusahaan sektor otomotif dan komponen tahun 2013-2017.

5. Current ratio, Debt to equity ratio, Net Profit Margin, dan Ukuran perusahaan berpengaruh secara simultan terhadap harga saham pada perusahaan sektor otomotif dan komponen tahun 2013-2017.

\section{II.METODOLOGI PENELITIAN}


Penelitian ini menggunakan metode kuantitatif dengan jenis data sekunder yang diperoleh dari Bursa Efek Indonesia sektor otomotif dan komponen tahun 2013-2017.

\section{II.1. Populasi dan Sampel}

Penelitian ini terdiri dari 13 perusahaan dengan teknik pengambilan sampel purposive sampling dengan beberapa kriteria sebagai berikut:

1. Perusahaan sektor otomotif dan komponen yang terdaftar di Bursa Efek Indonesia tahun 2013 - 2017.

2. Perusahaan sektor otomotif dan komponen yang mempublikasikan laporan keuangan secara lengkap di Bursa Efek Indonesia tahun 2013 - 2017.

3. Perusahaan sektor otomotif dan komponen yang memiliki laba/tidak rugi Bursa Efek Indonesia pada tahun $2013-2017$.

Sampel tabel 2.1 sebanyak 13 perusahaan memiliki kriteria sebagai berikut:

Tabel 2.1 Sampel Penelitian

\begin{tabular}{|c|l|c|}
\hline No. & \multicolumn{1}{|c|}{ Kriteria } & Jumlah Sampel \\
\hline 1. & $\begin{array}{l}\text { Perusahaan sektor otomotif dan komponen yang } \\
\text { terdaftar di BEI tahun 2013 - 2017. }\end{array}$ & 13 \\
\hline 2. & $\begin{array}{l}\text { Perusahaan sektor otomotif dan komponen yang tidak } \\
\text { mempublikasikan laporan keuangan secara lengkap di } \\
\text { BEI pada tahun 2013 - 2017. }\end{array}$ \\
\hline 3. & $\begin{array}{l}\text { Perusahaan sektor otomotif dan komponen yang } \\
\text { mengalami kerugian pada di BEI tahun 2013 - 2017. }\end{array}$ & $(6)$ \\
\hline Jumlah Sampel Penelitian & 6 \\
\hline
\end{tabular}

Berdasarkan tabel 2.1 diatas menunjukkan bahwa dari 13 perusahaan terdapat 6 perusahaan yang memenuhi kriteria penelitian pada perusahaan sektor otomotif dan komponen yang terdaftar di BEI pada tahun 2013-2017.

\section{II.2. Definisi Operasional}

\begin{tabular}{|c|c|c|c|c|}
\hline No & Voniobl & Dofinic: & & \\
\hline 1 & Current ratio $\left(\mathrm{X}_{1}\right)$ & $\begin{array}{c}\text { Current ratio } \\
\text { merupakan } \\
\text { rasio yang } \\
\text { menggunakan } \\
\text { aktiva } \\
\text { lancarnya untuk } \\
\text { memenuhi } \\
\text { kewajiban } \\
\text { lancarnya. } \\
\text { Novitasari \& } \\
\text { Herlambang } \\
(2015) \\
\end{array}$ & $\begin{array}{c}\text { Current ratio }= \\
\frac{\text { Aktiva lancar }}{\text { Hutang lancar }} \times 100 \%\end{array}$ & Rasio \\
\hline 2 & $\begin{array}{l}\text { Debt to equity ratio } \\
\left(\mathrm{X}_{2}\right)\end{array}$ & $\begin{array}{l}\text { Debt to equity } \\
\text { ratio }\end{array}$ & $\begin{array}{c}\text { Debt equity ratio = } \\
\frac{\text { Total Hutang }}{\text { Total Ekutas }} \times 100 \%\end{array}$ & Rasio \\
\hline
\end{tabular}


Jurnal Ekonomi \& Ekonomi Syariah Vol 3 No 1, Januari 2020

E-ISSN : 2599-3410 | P-ISSN : 4321-1234

DOI : https://doi.org/10.36778/jesya.v3i1.138

\begin{tabular}{|c|c|c|c|c|}
\hline & & $\begin{array}{c}\text { merupakan } \\
\text { rasio hutang } \\
\text { yang } \\
\text { menggunakan } \\
\text { ekuitas untuk } \\
\text { melunasi } \\
\text { liabilitasnya. } \\
\text { Dewi \& } \\
\text { Sauryana } \\
\text { (2013) }\end{array}$ & & \\
\hline 3 & Net profit margin $\left(\mathrm{X}_{3}\right)$ & $\begin{array}{c}\text { Net profit } \\
\text { margin } \\
\text { merupakan } \\
\text { rasio yang } \\
\text { membandingka } \\
\text { n antara laba } \\
\text { bersih dengan } \\
\text { penjualan. } \\
\text { Irfrianto (2015) }\end{array}$ & $\begin{array}{l}\text { Net profit margin = } \\
\frac{\text { Laba bersih }}{\text { Penjualan }} \text { X } 100 \%\end{array}$ & Rasio \\
\hline 4 & $\begin{array}{l}\text { Ukuran perusahaan } \\
\qquad\left(\mathrm{X}_{4}\right)\end{array}$ & $\begin{array}{c}\text { Ukuran } \\
\text { perusahaan } \\
\text { merupakan } \\
\text { skala besar } \\
\text { kecilnya suatu } \\
\text { perusahaan } \\
\text { yang dapat } \\
\text { ditentukan } \\
\text { berdasarkan } \\
\text { total aktiva } \\
\text { yang dimilki. } \\
\text { Putranto \& } \\
\text { Darmawan } \\
\text { (2018) }\end{array}$ & Size $=$ Log Total Aktiva & Rasio \\
\hline 5 & Harga saham (Y) & $\begin{array}{l}\text { Harga saham } \\
\text { merupakan } \\
\text { harga berupa } \\
\text { saham yang } \\
\text { terdapat di } \\
\text { pasar modal } \\
\text { yang dapat } \\
\text { digunakan } \\
\text { sebagai } \\
\text { investasi. Egam } \\
\text { dkk (2017) }\end{array}$ & $\begin{array}{l}\text { Harga saham dapat } \\
\text { diambil dari harga } \\
\text { penutupan masing- } \\
\text { masing perusahaan. }\end{array}$ & Rasio \\
\hline
\end{tabular}

\subsection{Uji Asumsi Klasik}

\subsubsection{Uji Normalitas}

(Ghozali, 2016:154;158).Uji ini dilakukan untuk melihat bagaimana residual dapat 
berdistribusi dalam suatu model regresi yang ditetapkan. Uji statistik One Sample KolmogorovSmirvov merupakan uji yang digunakan untuk menguji normalitas variabel penganggu dengan hipotesis sebagai berikut:

$\mathrm{H}_{0}$ : Data residual berdistribusi normal

$\mathrm{H}_{\mathrm{a}}$ : Data residual berdistribusi tidak normal

Hasil dari dapat dikatakan berdistribusi dengan normal atau uji statistik one sample kolmogorov-smirnov > 0,05 maka $\mathrm{H}_{0}$ diterima, dan $\mathrm{H}_{\mathrm{a}}$ ditolak.

\section{II.3.2. Uji Multikolinearitas}

(Ghozali, 2016:103),tujuan uji multikolinearitas adalah untuk menyimpulkan apakah adanya ditemukan atau tidak korelasi antara variabel bebas yang diuji. Uji ini dapat dilihat berdasarkan dari nilai Variance Inflation Factor (VIF) dan nilai tolerance.Hasil yang didapat menyimpulkan bahwa model regesi tersebut baik atau tidak. Model regresi yang baik akan menunjukkan tidak adanya korelasi yang terjadi antara variabel bebas. Nilai yang menunjukkan adanya mutikolinearitas adalah nilai tolerance $\leq 0.10$ atau sama dengan nilai $\mathrm{VIF} \geq 10$.

\section{II.3.3. Uji Autokorelasi}

(Ghozali, 2016:116-117), tujuan uji autokorelasi adalah untuk menyimpulkan apakah tinggi atau tidaknya hubungan korelasi antar residual. Cara yang digunakan adalah dengan melihat dari uji non-parametric run test apakah tidak terdapat hubungan korelasi antar residual dan sebaliknya. Apabila terlihat bahwa probabilitas signifikannya diatas taraf kepercayaan 5\%, maka tidak terjadinya autokorelasi pada model regresi.

\section{II.3.4. Uji Heterokedastisitas}

(Ghozali, 2016:134),tujuan uji heteroskedastisitas adalah untuk menyimpulkan apakah terdapat kesamaan atau tidak antar variance dari residual. Model regresi yang baik akan menunjukkan tidak terjadinya heteroskedastisitas. Cara untuk mendeteksinya ialah dengan melihat grafik scatterplot, dilihat bahwa tidaknya ada pola yang jelas, dan titik-titik yang menyebar diantara angka 0 pada sumbu Y, maka tidak terjadinya heteroskedastisitas. Cara lain yang digunakan dengan melihat uji glejser pada model regresi. Apabila terlihat bahwa probabilitas signifikannya diatas taraf kepercayaan 5\%, maka tidak terjadinya heteroskedastisitas pada model regresi.

\section{II.4. Model Analisis Data Penelitian}

\section{II.4.1. Model Penelitian}

Model regresi yang digunakan dalam penelitian ini adalah sebagai berikut:

$$
\mathrm{Y}=\mathrm{a}+\mathrm{b}_{1} \mathrm{X}_{1}+\mathrm{b}_{2} \mathrm{X}_{2}+\mathrm{b}_{3} \mathrm{X}_{3}+\mathrm{b}_{4} \mathrm{X}_{4}+\mathrm{e}
$$

Keterangan :

Y

a

$b_{1}, b_{2}, b_{3}, b_{4}$

$\mathrm{X}_{1}$

$$
=\text { Harga Saham }(\mathrm{Rp})
$$$$
=\text { Konstanta }
$$

$=$ Koefisien Regresi Variabel $\mathrm{X}_{1}$ (Current Ratio), $\mathrm{X}_{2}$ (Debt to Ratio), $\mathrm{X}_{3}$ (Net Profit Margin), $\mathrm{X}_{4}$ (Size)

Equity

$=$ Variabel Current Ratio $(\%)$ 


$$
\begin{array}{ll}
\mathrm{X}_{2} & =\text { Variabel Debt to Equity Ratio (\%) } \\
\mathrm{X}_{3} & =\text { Variabel Net Profit Margin (\%) } \\
\mathrm{X}_{4} & =\text { Variabel Size }(\%) \\
\mathrm{e} & =\text { Persentase Kesalahan }(\alpha=5 \%)
\end{array}
$$

\section{II.4.2. Koefisien Determinasi}

(Ghozali, 2016:95),tujuan koefisien determinasi adalah untuk melihat apakah variabel independen dapat menjelaskan variabel dependen nya dengan menggunakan nilai adjusted $R$ square pada model regresi.

\section{II.4.3. Pengujian Hipotesis Secara Simultan (Uji-F)}

(Ghozali, 2016:96),tujuan uji F adalah untuk melihat apakah terdapat hubungan linear secara keseluruhan antara variabel dependen terhadap variabel independennya. Variabel independen dapat dikatakan berpengaruh jika nilai $\mathrm{F}$ hasil perhitungan lebih besar daripada nilai $\mathrm{F}$ tabel. Variabel independen dapat dikatakan berpengaruh jika nilai $\mathrm{F}$ hitung lebih besar daripada nilai $\mathrm{F}$ tabel. Variabel independen dapat dikatakan signifikan, jika nilai signifikan tabel lebih kecil dari 0,05 .

\section{II.4.4. Pengujian Hipotesis Secara Parsial (Uji-t)}

(Ghozali, 2016:97),tujuan uji-t adalah untuk melihat apakah setiap masing-masing variabel independen memiliki pengaruh secara individual terhadap variabel dependennya. Variabel independen dapat dikatakan berpengaruh jika nilai t hitung lebih besar daripada nilai $t$ tabel. Variabel independen dapat dikatakan signifikan, jika nilai signifikan tabel lebih kecil dari 0,05 .

\section{HASIL PENELITIAN DAN PEMBAHASAN}

\section{III.1. Hasil Penelitian \\ III.1.1. Statistik Deskriptif}

Sampel yang memenuhi kriteria penelitian ini ada sebanyak 6 perusahaan sektor otomotif periode 2013-2017, dan data penelitiannya yang diperoleh berjumlah 30. Hasil pengolahan data sampel dapat dilihat dari tabel sebagai berikut :

Tabel 3.1 Statistik Deskriptif

\begin{tabular}{ll|l|l|l|l} 
& $\mathrm{N}$ & Minimum & Maximum & Mean & Std. Deviation \\
\hline CR & 30 & 1,0473 & 5,1254 & 1,974707 &, 9730009 \\
\hline DER & 30 &, 1351 & 2,3839 &, 675997 &, 4701910 \\
\hline NPM & 30 &, 0012 &, 1744 &, 081560 &, 0470532 \\
\hline SIZE & 30 & 27,4059 & 33,3202 & 29,536647 & 1,8120527 \\
\hline HS & 30 & 325 & 8300 & 3083,80 & 2652,336 \\
\hline Valid N (listwise) & 30 & & & & \\
\hline
\end{tabular}

Berdasarkan tabel 3.1, nilai minimum Variabel CR sebesar 1,0473 yang diperoleh pada Perusahaan PT. Nipress, Tbk tahun 2015. Nilai maksimum CR sebesar 5,1254 yang diperoleh pada PT. Indospring, Tbk tahun 2017. Nilai rata-rata CR sektor otomotif periode 2013-2017 adalah 1,974707 .

Nilai minimum Variabel DER sebesar 0,1351 yang diperoleh pada Perusahaan PT. Indospring, Tbk tahun 2017. Nilai maksimum DER adalah sebesar 2,3839 diperoleh pada PT. 
Nipress, Tbk tahun 2015. Nilai rata-rata DER sektor otomotif periode 2013-2017 adalah 0,675997 .

Nilai minimum sebesar 0,0012 yang diperoleh pada Perusahaan PT. Indospring, Tbk tahun 2015. Nilai maksimum NPM adalah sebesar 0,1744 yang diperoleh pada Perusahaan PT. Selamat Sempurna, Tbk tahun 2016. Nilai rata-rata NPM sektor otomotif periode 2013-2017 adalah 0,81560 .

Nilai minimum Variabel ukuran perusahaan sebesar 27,4059 yang diperoleh pada Perusahaan PT. Nipress, Tbk tahun 2013. Nilai maksimum ukuran perusahaan adalah sebesar 33,3202 yang diperoleh pada Perusahaan PT. Astra Internasional, Tbk tahun 2017. Nilai rata-rata ukuran perusahaan sektor otomotif periode 2013-2017 adalah 29,536647.

Nilai minimum Variabel harga saham sebesar 325 yang diperoleh pada Perusahaan PT. Nipress, Tbk tahun 2013. Nilai maksimum harga saham adalah sebesar 8.300 yang diperoleh pada Perusahaan PT. Astra Internasional, Tbk tahun 2017. Nilai rata-rata harga saham sektor otomotif periode 2013-2017 adalah 3.083,80.

\section{III.2 Hasil Uji Asumsi Klasik}

Penelitian ini telah memenuhi persyaratan semua asumsi klasik yaitu data berdistrbusi normal, tidak terjadi multikolinearitas, tidak terjadi autokorelasi dan tidak terjadi heteroskedastisitas.

\section{III.2.1. Uji Normalitas}

Tabel 3.2

Uji Normalitas Kolmogorov Smirnov One-Sample Kolmogorov-Smirnov Test

\begin{tabular}{llr} 
& \multicolumn{2}{c}{$\begin{array}{c}\text { Unstandardized } \\
\text { Residual }\end{array}$} \\
\hline $\mathrm{N}$ & & 30 \\
\hline Normal & Mean &, 0000000 \\
\cline { 2 - 3 } Parameters $^{\mathrm{a}, \mathrm{b}}$ & Std. & 1536,81530507 \\
& Deviation &, 147 \\
\hline Most Extreme & Absolute &, 147 \\
\cline { 2 - 3 } Differences & Positive &,- 107 \\
\cline { 2 - 3 } & Negative &, 147 \\
\hline Test Statistic & &, $098^{\mathrm{c}}$ \\
\hline Asymp. Sig. (2-tailed) &
\end{tabular}
a. Test distribution is Normal.
b. Calculated from data.
c. Lilliefors Significance Correction.

Berdasarkan tabel 3.2, nilai signifikan diperoleh sebesar 0,098 >0,05. Hasil ini dapat disimpulkan jika data penelitian telah memenuhi persyaratan asumsi normalitas karena data telah berdistribusi normal.

\section{III.2.2. Uji Multikolinearitas}

Tabel 3.3

\section{Uji Multikoloniearitas}

\begin{tabular}{|c|c|c|c|}
\hline \multirow{2}{*}{\multicolumn{2}{|c|}{ Model }} & \multicolumn{2}{|c|}{ Collinearity Statistics } \\
\hline & & Tolerance & VIF \\
\hline \multirow[t]{2}{*}{1} & $\overline{C R}$ & ,469 & 2,133 \\
\hline & DER & ,577 & 1,732 \\
\hline
\end{tabular}




\begin{tabular}{lr|r}
\hline NPM &, 885 & 1,129 \\
\hline Size &, 758 & 1,320 \\
\hline
\end{tabular}

a. Dependent Variable: Harga_Saham

Berdasarkan tabel 3.3, hasil uji multikolinearitas menunjukkan nilai tolerance variabel current ratio $0.469>0,1$, debt to equity ratio $0.577>0.1$, Net Profit Margin $0.885>0.1$, Ukuran Perusahaan $0.758>0.1$, dan nilai VIF variabel current ratio $2.113<10$, debt to equity ratio $1.732<10$, net profit margin $1.129<10$, size $1.320<10$. Sehingga data penelitian dapat disimpulkan tidak terjadi multikolinearitas atau tidak terjadi regresi antar variabel independen.

\section{III.2.3. Uji Autokorelasi}

\begin{tabular}{|c|c|}
\hline $\begin{array}{r}\text { Tabel 3.4 Uji } \\
\text { Runs }\end{array}$ & $\begin{array}{l}\text { i Autokorelasi } \\
\text { s Test } \\
\text { Unstandardiz } \\
\text { ed Residual }\end{array}$ \\
\hline Test Value ${ }^{\mathrm{a}}$ & $-443,42265$ \\
\hline Cases < Test Value & 15 \\
\hline $\begin{array}{l}\text { Cases }>=\text { Test } \\
\text { Value }\end{array}$ & 15 \\
\hline Total Cases & 30 \\
\hline Number of Runs & 13 \\
\hline $\mathrm{Z}$ &,- 929 \\
\hline $\begin{array}{l}\text { Asymp. Sig. } \quad \text { (2- } \\
\text { tailed) }\end{array}$ & ,353 \\
\hline
\end{tabular}

Berdasarkan tabel 3.4, hasil uji autokorelasi menunjukkan nilai signifikan sebesar 0,353 $>0,05$ maka dapat disimpulkan data penelitian tidak terjadi autokorelasi.

\section{III.2.4. Uji Heteroskedastisitas}

1. Uji Grafik

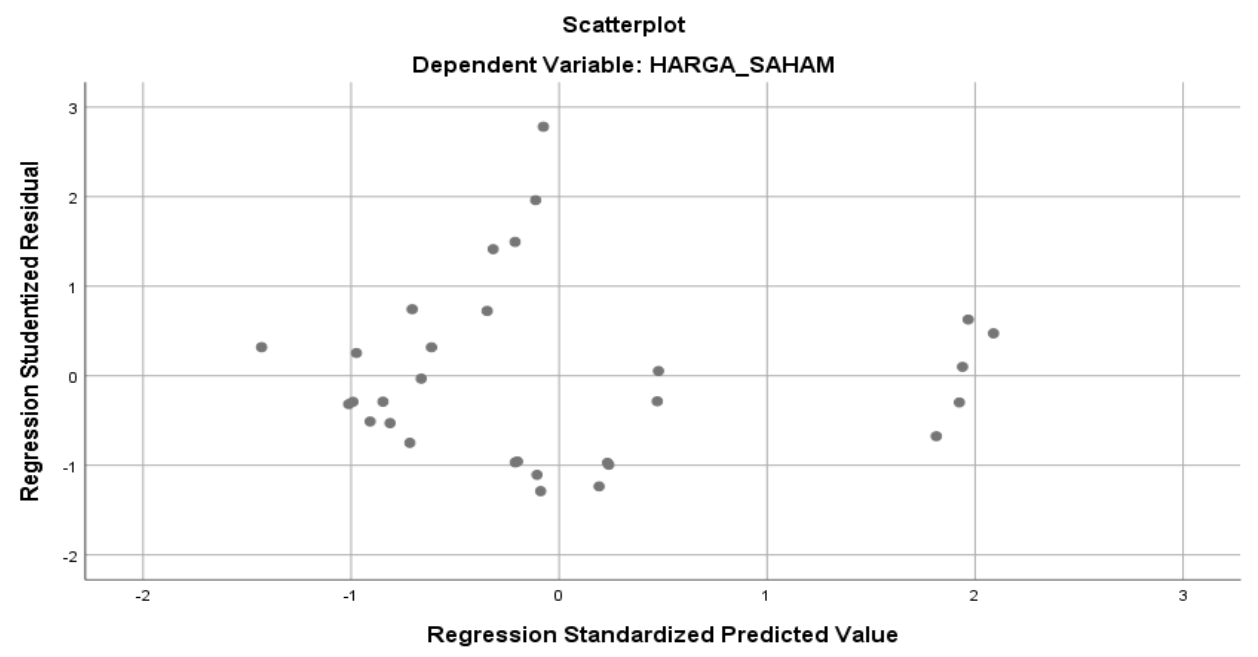

Gambar 3.2 Grafik Scatterplot

Berdasarkan gambar 3.2, terlihat titik-titik menyebar ke seluruh sumbu X dan sumbu Y sehingga dapat disimpulkan pada model regresi ini tidak terjadi heterokedastisitas. 


\begin{tabular}{|c|c|c|c|c|c|c|}
\hline \multicolumn{7}{|c|}{ Tabel 3.5 Uji Glejser } \\
\hline & \multicolumn{6}{|c|}{ Coefficients $^{\mathrm{a}}$} \\
\hline & \multirow[b]{2}{*}{ Model } & \multicolumn{2}{|c|}{ Unstandardized Coefficients } & \multirow{3}{*}{$\begin{array}{c}\text { Standardized } \\
\text { Coefficients } \\
\text { Beta } \\
\end{array}$} & \multirow[b]{2}{*}{$\mathrm{t}$} & \multirow[b]{2}{*}{ Sig. } \\
\hline & & B & Std. Error & & & \\
\hline 1 & (Constant) & 7488,876 & 3565,551 & & 2,100 &, 046 \\
\hline & $\mathrm{CR}$ & $-465,825$ & 259,214 &,- 464 & $-1,797$ &, 084 \\
\hline & DER & $-946,293$ & 483,320 &,- 455 & $-1,958$ & 061 \\
\hline & NPM & 6808,050 & 3900,378 & ,328 & 1,745 &, 093 \\
\hline & SIZE & $-180,080$ & 109,494 &,- 334 & $-1,645$ &, 113 \\
\hline
\end{tabular}

a. Dependent Variable: ABSUt

Berdasarkan tabel 3.5, hasil uji Glejser dengan nilai signifikan dari variabel current ratio $0,084>0,05$, debt to equity ratio $0,061>0,05$, net profit margin $0,093>0,05$, ukuran perusahaan $0,113>0,05$, dengan demikian dari hasil uji Glejser dapat disimpulkan telah memenuhi persyaratan karena tidak terjadi Heteroskedastisitas.

\section{III.3. Hasil Analisis Data Penelitian}

\section{III.3.1. Model Penelitian}

Model penelitian yang digunakan pengujian ini ialah analisis regresi linear berganda. Hasil uji analisis regresi linear berganda pada penelitian ini adalah :

Harga Saham $=7488,876-465,825$ CR $-946,293$ DER + 6808,050 NPM

180,080 Ukuran Perusahaan

Persamaan regresi linier berganda di atas yaitu :

1. Konstanta sebesar 7488,876 satuan menyatakan bahwa jika variabel CR, DER, NPM dan ukuran perusahaan bernilai 0 atau konstan maka harga saham sebesar 7488,876 satuan.

2. Koefisien regresi CR sebesar $-465,825$ satuan menyatakan bahwa setiap kenaikan 1 satuan CR akan menyebabkan penurunan harga saham sebesar $-465,825$ satuan.

3. Koefisien regresi DER sebesar -946,293 satuan menyatakan bahwa setiap kenaikan 1 satuan DER akan menyebabkan penurunan harga saham sebesar $-946,293$ satuan.

4. Koefisien regresi NPM sebesar 6808,050 satuan menyatakan bahwa setiap kenaikan 1 satuan NPM akan menyebabkan kenaikan harga saham sebesar 6808,050 satuan.

5. Koefisien regresi ukuran perusahaan sebesar $-180,080$ satuan menyatakan bahwa setiap kenaikan 1 satuan ukuran perusahaan akan menyebabkan kenaikan harga saham sebesar 180,080 satuan.

\subsubsection{Koefisien Determinasi Hipotesis}

Tabel 3.6. Uji Koefisien Determinasi Model Summary ${ }^{\mathbf{b}}$

\begin{tabular}{lr|r|lr|r} 
Model & R & R Square & $\begin{array}{l}\text { Adjusted } \\
\text { Square }\end{array}$ & R & $\begin{array}{l}\text { Std. Error of } \\
\text { the Estimate }\end{array}$ \\
\hline 1 &, $815^{\mathrm{a}}$ &, 664 &, 611 & 1655,201 \\
\hline
\end{tabular}

a. Predictors: (Constant), Size, DER, NPM, CR

b. Dependent Variable: Harga_Saham

Berdasarkan tabel 3.6, hasil yang diperoleh dari nilai Adjusted $R$ Square sebesar 0,610. Hal ini menyatakan bahwa variasi dari CR, DER, NPM dan ukuran perusahaan menjelaskan harga 
saham sebesar $61 \%$, sedangkan sisanya sebesar $39 \%$ dipengaruhi oleh variabel lain yang tidak diteliti.

\section{III.3.3 Pengujian Hipotesis Secara Simultan}

\section{Tabel 3.7. Uji F}

\begin{tabular}{llr|r|r|r|r} 
& \multicolumn{2}{c}{ ANOVA $^{\text {a }}$} & & \\
Model & Sum of & & & & \\
Squares & df & Mean Square & F & Sig. \\
\hline \multirow{2}{*}{1} & Regression & 135519393,6 & 4 & 33879848,406 & 12,366 &, $000^{\mathrm{b}}$ \\
\cline { 2 - 8 } & Residual & 68492237,17 & 25 & 2739689,487 & & \\
\cline { 2 - 8 } & Total & 204011630,8 & 29 & & & \\
\hline
\end{tabular}

a. Dependent Variable: HS

b. Predictors: (Constant), SIZE, DER, NPM, CR

Berdasarkan tabel 3.7, derajat bebas $1\left(\mathrm{df}_{1}\right)=4$, dan derajat bebas $2\left(\mathrm{df}_{2}\right)=25$, maka nilai $\mathrm{F}$ tabel pada taraf kepercayaan signifikansi 0,05 adalah 2.76. Hasil uji F menghasilkan nilai $F_{\text {hitung }}$ $=12.366>F_{\text {tabel }}=2,76$ dengan signifikansi 0,000. Karena $F_{\text {hitung }}>F$ tabel dan signifikansi 0,000 $<0,05$, maka $\mathrm{H}_{\mathrm{a}}$ diterima secara bersama-sama CR, DER, NPM dan ukuran perusahaan berpengaruh terhadap harga saham pada perusahaan sektor otomotif dan komponen tahun 20132017.

\section{III.3.4 Pengujian Hipotesis Secara Parsial}

\begin{tabular}{|c|c|c|c|c|c|c|}
\hline & & & $\begin{array}{l}\text { Tabel 3.8. Uj } \\
\text { Coefficients }\end{array}$ & & & \\
\hline & & Unstandardize & Coefficients & $\begin{array}{l}\text { Standardized } \\
\text { Coefficients }\end{array}$ & & \\
\hline Model & & B & Std. Error & Beta & $\mathrm{t}$ & Sig. \\
\hline 1 & (Constant) & $-28256,994$ & 6346,126 & & $-4,453$ &, 000 \\
\hline & CR & $-293,340$ & 461,360 &,- 108 &,- 636 & .531 \\
\hline & DER & $-335,474$ & 860,235 &,- 059 &,- 390 & ,700 \\
\hline & NPM & 12242,961 & 6942,065 & 217 & 1,764 & 090 \\
\hline & Size & 1054,564 & 194,882 & ,720 & 5,411 & 000 \\
\hline
\end{tabular}

a. Dependent Variable: Harga_Saham

Berdasarkan tabel 3.8, nilai t tabel untuk probabilitas 0,05 pada derajat bebas (df) 25 adalah sebesar 2,05954. Dengan hasil dari Uji t dapat dijelaskan sebagai berikut:

1. Nilai -t hitung > -t tabel atau -0,636 > -2,05954 dan signifikan 0,531 >0,05 maka $\mathrm{H}_{0}$ diterima artinya secara parsial CR tidak berpengaruh terhadap harga saham pada perusahaan sektor otomotif tahun 2013-2017.

2. Nilai -t hitung > -t tabel atau $-0,390>-2,05954$ dan signifikan $0,700>0,05$ maka $\mathrm{H}_{0}$ diterima artinya secara parsial DER tidak berpengaruh terhadap harga saham pada perusahaan sektor otomotif tahun 2013-2017.

3. Nilai thitung $<\mathrm{t}$ tabel atau 1,764 $<2,05954$ dan signifikan $0,090>0,05$ maka $\mathrm{H}_{0}$ diterima artinya secara parsial NPM tidak berpengaruh terhadap harga saham pada perusahaan sektor otomotif tahun 2013-2017. 
4. Nilai t hitung $>\mathrm{t}$ tabel atau 5,411 $>2,05954$ dan signifikan $0,000<0,05$ maka $\mathrm{H}_{\mathrm{a}}$ diterima artinya secara parsial ukuran perusahan berpengaruh dan signifikan terhadap harga saham pada perusahaan sektor otomotif tahun 2013-2017.

\section{III.4. Pembahasan Hasil Penelitian}

\section{III.4.1. Pengaruh Current Ratio Terhadap Harga Saham}

Berdasarkan hasil pengujian secara parsial menunjukan bahwa CR tidak berpengaruh terhadap harga saham pada perusahaan sektor otomotif tahun 2013-2017.)

Penelitian ini berbanding terbalik dengan penelitian Kundiman \& Hakim (2016) yang menyatakan bahwa CR berpengaruh terhadap harga saham.

Hal ini menunjukkan bahwa kemampuan CR dalam melunasi kewajiban lancar secara tepat waktu. Ini berarti investor tidak melihat CR sebagai keputusan untuk membeli saham. Faktor psikologi dari investor mengambil peranan yang cukup penting dalam pengambilan keputusan investasi dan tidak menggunakan analisis fundamental dalam pengambilan keputusannya.

Selain itu CR memiliki keterbatasan dimana CR merupakan suatu ukuran yang (tetap) yang mengukur sumber daya yang tersedia pada waktu tertentu untuk memenuhi kewajiban lancar. Sumber daya yang tersedia saat ini tidak cukup untuk merepresentasikan arus kas masuk di masa depan. Penelitian ini selaras dengan penelitian Pranata \& Kurnia (2013).

\section{III.4.2. Pengaruh Debt to Equity Ratio Terhadap Harga Saham}

Berdasarkan hasil pengujian secara parsial menunjukan bahwa DER tidak berpengaruh terhadap harga saham pada perusahaan sektor otomotif tahun 2013-2017.

Penelitian ini berbanding terbalik dengan penelitian Sajiyah (2016) yang menyatakan bahwa DER berpengaruh terhadap harga saham. Hal ini dikarenakan perusahaan kurang mampu memanfaatkan pendanaan dengan baik sehingga tidak dapat menghasilkan profit yang lebih tinggi. Hal tersebut menyebabkan DER tidak dapat dijadikan patokan untuk menilai kinerja keuangan yang mempengaruhi harga saham.

Perbandingan antara sumber dana perusahaan yang diperoleh dari pihak luar dengan yang disediakan oleh pemilik atau kata lain mengukur bagian modal sendiri dalam menjamin hutang.

Semakin besar peranan dana yang berasal dari luar dibandingkan modal sendiri, maka semakin besar resiko uang harus ditanggung oleh penyedia dana pembiayaan. Semakin kecil rasio semakin baik pembiayaan. Penelitian ini selaras dengan penelitian Novitasari \& Herlambang (2015)

\section{III.4.3. Pengaruh Net Profit Margin Terhadap Harga Saham}

Berdasarkan hasil pengujian secara parsial menunjukan bahwa NPM tidak berpengaruh terhadap harga saham pada perusahaan sektor otomotif tahun 2013-2017.

Penelitian ini berbanding terbalik dengan penelitian Dewi dan Hidayat (2014) yang menyatakan bahwa NPM berpengaruh terhadap harga saham.

Hal ini menunjukkan bahwa perbandingan laba bersih dengan penjualan tidak selalu diikuti oleh kenaikan harga saham. Semakin tinggi nilai NPM, maka semakin efisien perusahaan tersebut mendapatkan laba dari penjualan.

Perusahaan mampu menekan biaya - biaya dengan baik. Begitu juga sebaliknya, NPM yang semakin menurun menunjukkan ketidakmampuan perusahaan memperoleh laba atas penjualan dan mengelola biaya - biaya atas kegiatan operasionalnya, sehingga menyebabkan investor tidak tertarik untuk berinvestasi pada Perusahaan. Penelitian ini selaras dengan penelitian Faleria, dkk (2017). 


\section{III.4.4. Pengaruh Ukuran Perusahaan Terhadap Harga Saham}

Berdasarkan hasil pengujian secara parsial menunjukan bahwa ukuran perusahaan berpengaruh positif dan signifikan terhadap harga saham.

Penelitian ini berbanding terbalik dengan penelitian Wehantouw,dkk (2017) yang menyatakan bahwa Ukuran Perusahaan tidak berpengaruh terhadap harga saham.

Semakin besar suatu perusahaan menunjukkan perusahaan memiliki tahap petumbuhan penjualan yang sudah matang dan memiliki kapasitas aset yang cukup besar. Hal ini menimbulkan kepercayaan investor terhadap perusahaan sehingga investor lebih tertarik menanamkan dana dengan melihat besar kecilnya perusahaan. Penelitian ini selaras dengan penelitian Gunarso (2014).

\section{IV.KESIMPULAN DAN SARAN}

\section{IV.1. Kesimpulan}

Berdasarkan hasil analisis data yang mengacu pada tujuan penelitian, hipotesis, dan model analisis, maka dapat ditarik kesimpulan sebagai berikut:

1. Current Ratio tidak berpengaruh terhadap harga saham pada perusahaan sektor otomotif dan komponen yang terdaftar di BEI tahun 2013-2017.

2. Debt to Equity Ratio tidak berpengaruh terhadap harga saham pada perusahaan sektor otomotif dan komponen yang terdaftar di BEI tahun 2013-2017.

3. Net Profit Margin tidak berpengaruh terhadap harga saham pada perusahaan sektor otomotif dan komponen yang terdaftar di BEI tahun 2013-2017.

4. Ukuran perusahaan berpengaruh signifikan terhadap harga saham pada perusahaan sektor otomotif dan komponen yang terdaftar di BEI tahun 2013-2017

5. Current ratio, debt to equity ratio, net profit margin, dan ukuruan perusahan secara bersamaan berpengaruh signifikan terhadap harga saham pada perusahaan sektor otomotif dan komponen yang terdaftar di BEI tahun 2013-2017.

\section{IV.2. Saran}

Berdasarkan hasil kesimpulan yang telah dijelaskan diatas, maka saran-saran yang dapat diberikan adalah:

1. Bagi perusahaan, mengukur rasio likuiditas dengan baik dengan meningkatkan harta lancar, memperhatikan penggunaan hutang dengan bijaksana agar tidak menghambat keuntungan yang diinginkan, memperhatikan volume penjualan dengan mengamati peluang pasar agar dapat meningkatkan keuntungan secara maksimal, juga disarankan agar perusahaan mempertahankan aset yang ada karena aset yang besar dapat dijadikan jaminan untuk menambah hutang dan mendapatkan peluang investasi yang menguntungkan.

2. Bagi investor, disarankan untuk melihat besar kecilnya perusahaan sektor otomotif apabila ingin menginvestasikan dana di sektor tersebut.

3. Bagi peneliti selanjutnya, disarankan untuk menambahkan variabel selain dari variabel yang diteliti.

\section{DAFTAR PUSTAKA}

Alfiah, N., \& Diyani, L. A. (2018). Pengaruh ROE dan DER Terhadap Harga Saham pada Sektor Perdagangan. Jurnal Bisnis Terapan, 1(02), 47-54.

Amalya, N. T. (2018). Pengaruh Return on Asset, Return on Equity, Net Profit Margin dan Debt to Equity Ratio Terhadap Harga Saham. Jurnal SEKURITAS (Saham, Ekonomi, Keuangan dan Investasi), 1(3). 
Batubara, H. C. (2017). Pengaruh Return On Assets (ROA), Return on Equity (ROE), dan Debt to Equity Ratio (DER) Terhadap Harga Saham Pada Perusahaan Makanan Dan Minuman Yang Terdaftar Di Bursa Efek Indonesia Periode 2011-2015. Jurnal Ilmiah Kohesi, 1(1).

Bernardin, D. E. Y., \& Pebryyanti, D. I. (2016). Nilai Harga Saham Yang Dipengaruhi oleh Laba Bersih dan Ukuran Perusahaan. Jurnal Ecodemica: Jurnal Ekonomi, Manajemen, dan Bisnis, 4(1), 72-85.

Dewi, P. D. A., \& Suaryana, I. G. (2013). Pengaruh EPS, DER, dan PBV Terhadap Harga Saham. E-Jurnal Akuntansi, 215-229.

Egam, G. E., Ilat, V., \& Pangerapan, S. (2017). Pengaruh Return on Asset (ROA), Return on Equity (ROE), Net Profit Margin (NPM), dan Earning Per Share (EPS) terhadap Harga Saham Perusahaan yang Tergabung dalam Indeks LQ45 di Bursa Efek Indonesia Periode Tahun 2013-2015. Jurnal EMBA: Jurnal Riset Ekonomi, Manajemen, Bisnis dan Akuntansi, 5(1).

Faleria, R. E., Lambey, L., \& Walandouw, S. K. (2017). Pengaruh Current Ratio,Net Profit Margin dan Earning Per Share Terhadap Harga Saham Di Bursa Efek Indonesia (Studi Kasus Pada Sub Sektor Food And Beverages). Jurnal Riset Akuntansi Going Concern, 12(2).

Ghozali, I. 2016. Aplikasi Analisis Multivariate Dengan Program IBM SPSS 23. Semarang : Universitas Diponegoro.

Gunarso, P. (2014). Laba akuntansi, Leverage, dan Ukuran Perusahaan Terhadap Harga Saham di Bursa Efek Indonesia. Jurnal Keuangan dan Perbankan, 18(1).

Hutami, R. P. (2012). Pengaruh Dividend per Share, Return on Equity dan Net Profit Margin terhadap Harga Saham Perusahaan Industri Manufaktur yang Tercatat di Bursa Efek Indonesia Periode 2006-2010. Nominal, Barometer Riset Akuntansi dan Manajemen, $1(2)$.

Irfianto, I. (2015). Pengaruh Price Earning Ratio (PER), Net Profit Margin (NPM), dan Return on Equity (ROE) Terhadap Harga Saham Perusahaan Sub Sektor Telekomunikasi Pada Bursa Efek Indonesia. Jurnal Administrasi Bisnis, 3(2), 416-429.

Kundiman, A., \& Hakim, L. (2017). Pengaruh Current Ratio, Debt to Equity Ratio, Return on Asset, Return on Equity Terhadap Harga Saham Pada Indeks LQ 45 Di BEI Periode 20102014. Jurnal Ilmiah Among Makarti, 9(18).

Manoppo, V. C. O., Tewal, B., \& Jan, A. B. H. (2017). Pengaruh Current Ratio, DER, ROA Dan NPM Terhadap Harga Saham Pada Perusahaan Food and Beverages Yang Terdaftar Di BEI (Periode 2013-2015). Jurnal EMBA: Jurnal Riset Ekonomi, Manajemen, Bisnis dan Akuntansi, 5(2).

Medan, S. S. (2014). Pengaruh Net Profit Margin dan Return on Assets Terhadap Harga Saham pada Perusahaan Otomotif yang terdaftar di Bursa Efek Indonesia.

Novitasari, P., \& Herlambang, L. (2015). Pengaruh Current Ratio, Total Assets Turnover, Debt To Equity Ratio, dan Return On Equity terhadap Harga Saham pada Perusahaan Yang Terdaftar di JII Periode 2009-2013. Jurnal Ekonomi Syariah Teori dan Terapan, 2(4).

Nur'aidawati, (2018). Pengaruh Current Ratio (Cr), Total Asset Turnover (Tato), Debt To Equity Ratio (Der) Dan Return On Asset (Roa) Terhadap Harga Saham Dan Dampaknya Pada Nilai Perusahaan ( Studi Kasus pada Sepuluh Bank Terbesar yang terdaftar di Bursa Efek Indonesia Periode Tahun 2011 - 2015 ). Jurnal Sekuritas (Saham, Ekonomi, Keuangan dan Investasi), 1(3), 74.

Pranata, H. C., \& Kurnia, R. (2013). Pengaruh Profitabilitas, Likuiditas, Solvabilitas, Dan Kebijakan Dividen Terhadap Harga Saham. ULTIMA Accounting, 5(2), 81-98.

Putranto, A. D., \& Darmawan, A. (2018). Pengaruh Ukuran Perusahaan, Profitablitias, Leverage, dan Nilai Pasar Terhadap Harga Saham (Studi Kasus pada Perusahaan Pertambangan yang Terdaftar di Bursa Efek Indonesia Periode 2010-2016). Jurnal Administrasi 
Bisnis, 56(1).

Rahmadewi, P. W., \& Abundanti, N. (2018). Pengaruh EPS, PER, CR dan ROE terhadap Harga Saham di Bursa Efek Indonesia. None, 7(4).

Safitri. (2016). Pengaruh PER, ROA, dan DER terhadap Harga Saham pada Perusahaan Sub Sektor Lembaga Pembiayaan di Bursa Efek Indonesia. eJournal Administrasi Bisnis.

Sajiyah, I. (2016). Pengaruh Current Ratio, Debt to Equity Ratio dan Return On Investment Terhadap Harga Saham Perusahaan Food \& Beverages. Jurnal Akademika, 14(1), 32-39.

Setiyawan, I., \& Pardiman, P. (2014). Pengaruh Current Ratio, Inventory Turnover, Time Interest Earned dan Return on Equity Terhadap Harga Saham Pada Perusahaan Manufaktur Sektor Barang Konsumsi Yang Terdaftar di BEI Periode 2009-2012. Nominal, Barometer Riset Akuntansi dan Manajemen, 3(2).

Sukarno, Sitawati, \& Sam'ani. (2016). Pengaruh Profitabilitas, Pertumbuhan Penjualan Dan Ukuran Perusahaan Terhadap Harga Saham dengan Struktur Modal Sebagai Variabel Intervening (Studi Empiris Perusahaan LQ 45 Di Bursa Efek Indonesia).Dharma Ekonomi, 67.

Valianti, R. M. (2016). Pengaruh Debt to Assets Ratio, Debt to Equity Ratio, Return On Assets dan Net Profit Margin Terhadap Harga Saham Pada Perusahaan Indeks LQ-45 di Bursa Efek Indonesia. Jurnal Media Wahana Ekonomika, 13(1).

Watung, R. W., \& Ilat, V. (2016). Pengaruh Return on Asset (ROA), Net Profit Margin (NPM), Dan Earning Per Share (EPS) Terhadap Harga Saham Pada Perusahaan Perbankan Di Bursa Efek Indonesia Periode 2011-2015. Jurnal EMBA: Jurnal Riset Ekonomi, Manajemen, Bisnis dan Akuntansi, 4(2).

Wehantouw, J. D., Tommy, P., \& Tampenawas, J. L. (2017). Pengaruh Struktur Modal, Ukuran Perusahaan, dan Profitabilitas Terhadap Harga Saham pada Perusahaan Industri Sektor Makanan dan Minuman yang Terdaftar di Bursa Efek Indonesia Periode 20122015. Jurnal EMBA: Jurnal Riset Ekonomi, Manajemen, Bisnis dan Akuntansi, 5(3).

Zaki, M., \& Islahuddin, M. S. (2017). Pengaruh Profitablitas, Leverage Keuangan dan Ukuran Perusahaan Terhadap Harga Saham (Studi Pada Perusahaan Manufaktur Yang Terdaftar di Bursa Efek Indonesia Periode 2005-2014). Jurnal Administrasi Akuntansi: Program Pascasarjana Unsyiah, 6(3). 